\title{
Communication
}

[Comunicação]

\section{Cellular enzyme values in hunter/jumper and dressage horses with dermatophytosis}

[Valores de enzimas celulares em cavalos de caça e de esportes com ou sem dermatofitose]

\author{
K. Ural ${ }^{1 *}$, B. Yağcl ${ }^{2}$, N. Ocal \\ ${ }^{1}$ Adnan Menderes University, Faculty of Veterinary, Department of Internal Medicine \\ Aydin - Turkey \\ ${ }^{2}$ Kırlkale University, Faculty of Veterinary, Department of Internal Medicine \\ Kirikkale - Turkey
}

Dermatophytosis, one of the most common equine skin diseases (Sloet van OldruitenborghOosterbaan et al., 1994) is a mycodermatological disease caused by keratinophilic fungi Microsporum or Trichophyton species (Connole, 1990; Pal et al., 1994). The most commonly isolated fungi from animal cases were T. verrucosum, T. mentagrophytes, and Microsporum species (Abou-Gabal et al., 1976; Al-Ani et al., 1995). T. equinum is the most commonly involved agent in horses and it is reported in many countries (Hasegawa and Usui, 1975; Al-Ani et al., 2002).

Aspartate aminotransferase (AST), an enzyme found in many tissues and organs, mostly active in the liver (Zimmerman et al., 1968), is a sensitive marker of liver damage when its serum activity is increased (Meyer and Harvey, 1998). Activity of AST in horses is much higher than in other animals (Cornelius et al., 1958), and is influenced by muscle activity (Weigert et al., 1980), species, breed, and age. Working horses have a higher activity in contrast to horses at rest (Weigert et al., 1980).

Gamma-glutamyltransferase (GGT) is another enzyme usually found in cells with high secretion or absorption rates. Especially, in liver, kidneys, pancreas, intestines, and spleen, its activity is higher (Tennant, 1997). In the horse, the GGT activity is relatively high in the liver. GGT activity is suggested as a priority serum marker for the diagnosis of hepatic disease in

Recebido em 17 de novembro de 2008

Aceito em 31 de agosto de 2009

Autor para correspondência (corresponding author)

Email: uralkerem@gmail.com animals (Kramer and Hoffman, 1997; Olsman and Sloet van Oldruitenborgh-Oosterbaan, 2004), as well as in equines GGT carries an important role in sick horses with hepatic disorders.

Other significant cellular enzymes are: alkaline phosphatese (ALP) and lactate dehydrogenase (LDH). However, most of those enzymes also have high concentrations in other tissues. Therefore, the latter aforementioned enzymes are not recognized specifically for the diagnosis of hepatic disorders in horses. However, it should be mentioned that in an attempt to support the diagnosis, the determination of those enzymes may be valuable (Schall, 1976).

To the present knowledge of the authors, there have been few studies previously that discussed the effect of dermatophytosis on biochemical parameters, in which mostly were performed in cattle (Kumar and Khurana, 2002; Atakisi et al., 2006; Karapehlivan et al., 2007). In fact, no previous study was performed analysing the relationship between dermatophytosis and hepatic functions in hunter/jumper and dressage horses in Turkey. Therefore, the aim of the present study was to investigate the activities of above mentioned enzymes in the sera samples of valuable dressage and hunter/jumper horses with dermatophytosis. Because there is lack of systematic data for those important parameters with regard to superficial mycotic diseases for these horses, the obtained results may be valuable contributors to a better understanding of biochemical processes in the horse with tricophytosis. 
Sixteen hunter/jumper and dressage horses (seven stallions and nine geldings), aging from two to seven-year-old were evaluated by complete physical examination and deemed eligible for including in the present study. The study was performed during early winter from 2006 to 2008. All animals were dressage or hunter/jumper horses. All cases were presented with a complaint related to dermatological problems; otherwise, all of those were healthy. None of the horses included in the study had been received medications for at least one month, in an attempt to exclude influence of any medications to the blood work-up.

Horses were deemed eligible for enrolment once they satisfied inclusion criteria. Primary and major criteria included positive fungal culture against Tricophyton equinum. In addition, the presence of alopecia, scaling, and focal mycotic lesions was another inclusion criteria. Differential diagnosis considered to account for skin lesions susceptible for tricophytosis included mite infestation, urticaria, bacterial folliculitis, autoimmune conditions, and endocrine diseases. Animals diagnosed to have any of those aforementioned conditions as detected previously by results of skin scrapings, cytology, fungal culture, food trial, haematology, biochemistry, and urinalysis, were excluded.

The lesions started as patches of raised hair and soreness. In about several days later, the hair detached leaving bald, grey, and shining areas approximately $2-5 \mathrm{~cm}$ diameter. The lesions were pruritic, with exudate and areas of hairless, and thickened skin. Moderate scaling was evident. All the horses had the exact clinical presentation. The shape, size, position, distribution, and time of the appearance of skin lesions were recorded. The lesions were present for 15-25 days duration. None of the horses had had nodular lesions.
An age-matched control group $(n=16$ : seven stallions and nine geldings), aing from two to seven-year-old consisted of healthy hunter/jumper and dressage horses with no disease condition. The skin of all animals was examined and a complete clinical examination of all affected animals was performed. Evaluation of the general state of the animals, temperature, pulse rate, respiratory rate, appetite, and morbidity rates were recorded.

Hair or scab samples were collected from all 16 horses. Collected samples were used both for microscopic examination and fungal culture. Hair sample was also pulled out from healthy horses for analysis. Fungal isolation was carried out by the cultivating method using selective agar medium for Trichophyton ${ }^{1}$. The identification of the dermatophytes was performed by the characteristics of the colony and morphology.

The activities of serum AST, alanine aminotransferase (ALT), LDH, ALP, and GGT were assayed colorimetrically according to the Standard procedures using commercially available diagnostic kits obtained from Biolabo Samaizy (France). Differences on serum biochemical analyses between the two groups were assessed by Mann-Whitney U test. All data are presented as mean \pm SE. Values were considered statistically significant when $\mathrm{P}<0.05$.

Concentrations of AST, ALT, LDH, ALP, and GGT activities in the serum samples of 16 hunter/jumper and dressage horses with naturally acquired dermatophytosis and those of a group of gender and age-matched healthy controls $(n=16)$ are shown in Table 1 . In addition, fungal isolation and microscopic examination results were shown in Table 1.

Table 1. Cellular enzyme activities in hunter/jumper horses with dermatophytosis and healthy horses

\begin{tabular}{lcc}
\hline Enzyme & Healthy controls & Dermatophytic horses \\
\hline Alanine aminotransferase (U/L) & $12.6 \pm 0.94$ & $12.7 \pm 0.95$ \\
Aspartate aminotransferase (U/L) & $207.5 \pm 2.67$ & $209.8 \pm 3.69$ \\
Lactate dehydrogenase (U/L) & $216.0 \pm 10.94$ & $198.7 \pm 9.00$ \\
Gamma-glutamyltransferase (U/L) & $19.3 \pm 0.90$ & $17.9 \pm 1.09$ \\
Alkaline phosphatase(U/L) & $205.5 \pm 5.64$ & $208.3 \pm 4.18$ \\
\hline
\end{tabular}

There were no significant differences between groups $(\mathrm{P}>0.05)$

${ }^{1}$ Difco Laboratories - Detroit, USA. 
Comparison of serum biochemical variables between dermatophytic horses and healthy control group, showed no differences $(\mathrm{P}>0.05)$ for mean values of AST, ALT, LDH, ALP, and GGT.

According to the research results, concentrations of AST, ALT, LDH, ALP, and GGT enzyme activities in the sera samples of hunter/jumper and dressage horses with dermatophytosis and those of a group of gender and age-matched healthy controls, remained within the known values recorded in horses. The normal activity of AST, ALT, LDH, ALP, and GGT enzymes during the course of dermatophytosis could be attributable to no influence of the disease on the activities of hepatic enzymes investigated. Therefore, it may be suggested that dermatopyhtosis had no apparent effect on hepatic function in horses enrolled in this study. The obtained results could serve for a better understanding of biochemical processes in dermatophytosis, for estimating their physiological status, and for diagnostic purposes.

Dermatophytosis causes infection in the hair roots of horses (Connole, 1990) and colonization is limited to the dead keratinized tissue of the stratum corneum, resulting in inflammatory reactions (Weitzman and Summerbell, 1995). It has been well recognized and documented that dermatophytes may be able to produce proteolytic and lipolytic enzymes (Morganti et al., 1992) that have major roles in mycotic invasion resulting in pathogenesis (Muhsin et al., 1997; Schaufuss and Steller, 2003). During the course of invasion process, the metabolic products of the fungi may even penetrate the liver via passing through the skin and circulatory system (Atakisi et al., 2006). Similarly, the pathogenesis of another fungi, disseminated Candida infection includes penetration and adhesion from a colonized mucosal location to internal parenchymal organs, such as in the liver. The liver has been invaded by Candida albicans after intraperitoneal infection of mice (Felk et al., 2002). Given the fact that fungal invasion may be capable of reaching the liver, the primary interest of the authors and reason for performing this study was to investigate the possible influence of dermatophytosis on hepatic functions in horses.

When host cells of the liver are damaged, the organ-specific enzymes such as AST, ALT, and GGT (in liver) may be released and are detectable in the blood. Therefore, in this study the authors used all these enzyme activities in the blood to monitor the potential of dermatophyte pathogens to damage the hepatic tissue. Indeed, no elevations were detected in horses with dermatophytposis. Therefore, it should be suggested that dermatophyte infection was unable to cause hepatic tissue damage in the horses enrolled in this study, by means of blood work-up.

On the other hand, there have been few studies investigating the influence of dermatophytosis on biochemical parameters, mostly performed in cattle in Turkey (Atakisi et al., 2006; Karapehlivan et al., 2007). In a previous study regarding biochemical functions in cattle with dermatophytosis, statistically significant increases on GGT, AST, ALT, and LDH levels in dermatophytic cattle were found (Atakisi et al., 2006). In contrast, in another study, no statistical difference was reported in AST and ALT levels between healthy and dermatophytic cattle (Kumar and Khurana, 2002). In fact to the knowledge no previous study has been performed analysing the relationship between dermatophytosis and hepatic functions in hunter/jumper and dressage horses in Turkey.

According to the research results, concentrations of AST, ALT, LDH, ALP, and GGT enzyme activities remained within the known values in the sera samples of hunter/jumper and dressage horses with dermatophytosis and those of a group of gender and age-matched healthy controls. In addition, no statistically significant differences were found for mean values of the cellular enzymes investigated. The normal activity of AST, ALT, LDH, ALP, and GGT enzymes during the course of dermatophytosis could be attributable to no influence of the disease on the activities of hepatic enzymes investigated. Therefore, it may be suggested that dermatopyhtosis had no apparent effect on hepatic function in horses enrolled in this study. The obtained results could serve for a better understanding of biochemical processes in dermatophytosis, for estimating their physiological status, and for diagnostic purposes. This fact indicates the necessity of further studies with larger horse populations to better understanding of the aetiology of dermatophytosis in horses, which will become the prior subject of our next study.

Keywords: horse, dermatophytosis, cellular enzyme 


\section{RESUMO}

Valores de enzimas celulares envolvendo testes da função hepática em 16 equinos de caça e de salto com tricofitose naturalmente adquirida foram comparados com 16 equinos saudáveis, para avaliar os efeitos da doença sobre as atividades dessas enzimas hepáticas. Todos os cavalos diagnosticados com tricofitose ou positivos para Tricophyton equinum foram isolados. Soro aspartato aminotransferase (AST), alanina aminotransferase (ALT), lactato desidrogenase (LDH), fosfatase alcalina (ALP) e gama glutamil transferase (GGT) foram analisados por calorimetria. Não houve diferenças significativas entre os animais doentes e os saudáveis quanto às atividades enzimáticas.

Palavras-chave: equino, dermatofitase, enzimas celulares Ural

\section{REFERENCES}

ABOU-GABAL，M.; EL-GALIL， G.A.; ELNOR, E.A. et al. Animal ringworm in Upper Egypt. Sabouraudia, v.14, p.33-36, 1976.

AL-ANI, F.K.; AL-BASSAM, L.S.; ALSALAHI, K.A. Epidemiological study of dermatomycosis due to Trichophyton schoenleinii in camels in Iraq. Bull. Anim. Health Prod. Africa, v.43, p. 87-92, 1995.

AL-ANI. F.K.; YOUNES, F.A.; ALRAWASHDEH, O.F. Ringworm infection in cattle and horses in Jordan. Acta Vet. Brno., v.71, p.55-60, 2002.

ATAKISI, E.; KARAPEHLIVAN, M.; ATAKISI, O. et al. Adenosine deaminase and biochemical liver function tests in the dermatophytic cattle. Bull. Vet. Inst. Pulawy, v.50, p.481-483, 2006.

CONNOLE, M.D. Review of animal mycoses in Australia. Mycopathology, v.111, p.133-142, 1990.

CORNELIUS, C.E.; BISHOP, J.; SWITZER, J. et al. Serum and tissue transaminase activities in domestic animals. Cornell Vet., v.19, p.116-126, 1958.

FELK, A.; KRETSCHMAR, M.; ALBRECHT, A. et al. Candida albicans hyphal formation and the expression of the Efg1-regulated proteinases Sap4 to Sap6 are required for the invasion of parenchymal organs. Infect. Immun., v.70, p.3689-3700, 2002.

HASEGAWA, A.; USUI, K. Isolation of Trichophyton equinum and Microsporum canis from equine dermatophytosis. Jpn. J. Med. Microbiol., v.19, p.11-13, 1975.

KARAPEHLIVAN, M.; UZLU, E.; KAYA, N. et al. Investigation of some biochemical parameters and the antioxidant system in calves with dermatophytosis. Turk. J. Vet. Anim. Sci., v.31, p.1-5, 2007.

KRAMER, J.W.; HOFFMAN, W.E. Clinical enzymology. In: KANEKO, J.J.; HARVEY, J.W.; BRUSS, M.L. (Ed.). Clinical Biochemistry of Domestic Animals. 5.ed., San Diego: Academic, 1997. p.303-325.

KUMAR, A.; KHURANA, R. Effect of dermatophytosis on haematobiochemical parameters in cattle. Hayrana Vet., v.41, p.44-47, 2002.

MEYER, D.J.; HARVEY, J.W. Veterinary Laboratory Medicine. Interpretation and Diagnosis. 2. ed. Philadelphia: W.B Saunders, 1998. p.157-187.

MORGANTI, L.; TAMPIERI, M.P.; GALUPPI, R.; et al. Morphological and biochemical variability of Microsporum canis strains. Eur. J. Epidemiol., v.8, p.340-345, 1992.

MUHSIN, T.M.; AUBAID, A.H.; ALDUBOON, A.H. Extracellular enzyme activities of dermatophytes and yeast isolates on solid media. Mycoses, v.40, p.465-469, 1997.

OLSMAN, A.F.; SLOET VAN OLDRUITENBORGH-OOSTERBAAN, M.M. Primary liver disease in the horse. Tijdschr. Diergeneeskd., v.129, p.510-522, 2004.

PAL, M.; MATSUAKA, N.; LEE, C.W. Clinical and mycological observations on equine ringworm due to Microsporum gypseum. Korean J. Vet. Clin. Med., v.11, p.5-8, 1994.

SCHALL, W.D. Laboratory diagnosis of hepatic disease. Vet. Clin. N. Am., v.6, p.679-686, 1976.

SCHAUFUSS, P.; STELLER, U. Haemolytic activities of Trichophyton species. Med. Mycol., v.41, p.511-516, 2003. 
SLOET VAN OLDRUITENBORGHOOSTERBAAN, M.M.; KLEIN, W.R.; MISDORP, W. Differential diagnosis of nonhealing 'fungal' patches in horses. Tijdschr. Diergeneeskd., v.119, p.756-759, 1994.

TENNANT, B.C. Hepatic function. In: KANEKO, J.J.; HARVEY, J.W.; BRUSS, M.L. (Ed.). Clinical Biochemistry of Domestic Animals. 5.ed., San Diego: Academic, 1997. p. 327-352.

WEIGERT, P.; SCHECK, K.; LEMMER, B. et al. Labordiagnostische haflinger pferden und maultieren (Tragtiere der Bundeswehr) enzymaktivitäten im serum. Tierärztl. Praxis, v.8, p.387, 1980 .
WEITZMAN, I.; SUMMERBELL, R.C. The Dermatophytes. Clin. Microbiol. Rev., v.8, p.240-259, 1995.

ZIMMERMAN, H.J.; DUJOVNE, C.A.; LEVY, R. The correlation of serum levels of two transaminases with tissue levels in six vertebrate species. Comp. Biochem. Physiol., v.25, p.10811089, 1968. 